\title{
Vascular cell-matrix adhesion in development and cancer
}

\author{
CHRISTINA ARAPATZI1,\#, GEORGIA ROUNI ${ }^{1,2, \#, ~ V A S S I L I K I ~ K O S T O U R O U ~}{ }^{1, *}$ \\ 'Institute of Biolnnovation, Biomedical Sciences Research Centre "Alexander Fleming", Vari-Athens, Greece, \\ ${ }^{2}$ Department of Biology, University of Patras, Greece
}

\begin{abstract}
The development and homeostasis of vertebrate organisms depend on the "tree of life", in other words, the intricate network of vascular tubes composed of endothelial cells attached to the basement membrane and surrounded by perivascular cells. Although many studies have revealed the fundamental role of cytokines, growth factors and Notch signalling in vascular morphogenesis, we still lack sufficient understanding of the molecular mechanisms controlling the various steps of the angiogenic processes. Emerging data highlight that cell adhesions are key players in vascular morphogenesis. In this review, we focus on endothelial cells and we present the current state of knowledge regarding the role of cell-matrix adhesions in developmental and tumour angiogenesis, attained mainly from genetic studies and animal models.
\end{abstract}

KEYWORDS: endothelial, angiogenesis, adhesion, migration, cancer

\section{Introduction}

Blood vessels are crucial for the life of all vertebrates. Besides delivering nutrients and oxygen and removing waste metabolites, blood vessels provide instructive cues to the developing organs, control immune responses and form specific niches for stem cells, facilitating tissue homeostasis and regeneration. It is not surprising, therefore, that the vascular system is the first system to develop in the vertebrate embryo (Risau, 1997). The vascular system consists of blood vessels -further divided into arteries, veins and capillaries- and lymphatics -arranged into ducts, large collecting vessels and smaller capillaries. The basic unit of the vascular system is the endothelium, a monolayer of endothelial cells (ECs) attached to each other and to the extracellular matrix (ECM), named basement membrane (Kostourou and Papalazarou, 2014). Depending on the vessel type, other perivascular cells (pericytes and smooth muscle cells) are firmly or more loosely attached to ECs (Potente et al., 2011). EC adhesion is key to blood vessel structure and thus critically influences vascular development, homeostasis and function. This review will focus on the significance of cell-matrix adhesion in regulating vascular morphogenesis, and present recent advances and in vivo studies that reveal the key factors governing EC adhesion.

\section{Fundamentals of vascular development}

The vascular system forms in the embryo, initially by the process of vasculogenesis, namely the de novo coalescence of mesoderm- derived endothelial progenitors, termed angioblasts. In the yolk sac, angioblasts form the blood islands that give rise to the primary plexus, and in the embryo proper, angioblasts arrange into primitive tubes that will differentiate into the dorsal aorta and the cardinal vein (Risau, 1997). The intricate network of blood vessels is thus produced by the growth and the remodelling of pre-existing vessels, a process known as angiogenesis. There are two main types of angiogenesis: the formation of new vascular branches through sprouting angiogenesis (Potente et al. 2011)and the splitting of vessels by intussusception (Makanya et al. 2009). In certain pathological cases, circulating precursor endothelial cells could be integrated into fast-growing vessels (Pearson, 2010).Moreover, tumours exploit additional ways to fuel their exponential growth and obtain routes for metastasis, co-opting the host vasculature or forming tube networks by vascular mimicry (Lugano et al. 2019).

\section{Sprouting angiogenesis}

The term "angiogenesis" is frequently employed in the literature to denote angiogenic sprouting, namely, the development of new branches from pre-existing vessels (Fig. 1). This is a multistep process that starts with the activation of quiescent ECs caused

\footnotetext{
Abbreviations used in this paper: 3D, three-dimension; E, embryonic day; EC, endothelial cell; ECM, extracellular matrix; FAK, focal adhesion kinase; HUVEC, human umbilical vein endothelial cell; ILK, integrin-linked kinase; PI3K, phosphoinositide-3-kinase; PINCH, particularly interesting new cysteine-histidinerich protein; siRNA, small interference RNA; VEGF/VEGFR, vascular endothelial growth factor/ receptor.
}

\footnotetext{
*Address correspondence to: Vassiliki Kostourou. 34 Fleming str. Vari-Athens 166 72, Greece. Tel: +30 2109654465. E-mail: Kostourou@fleming.gr web: https://www.fleming.gr/research/ibi/researchers/kostourou-lab | https://orcid.org/0000-0001-7053-6247

\# Equal contribution.
}

Submitted: 23 October, 2021; Accepted: 31 October, 2021; Published online: 22 November, 2021. 
Fig. 1. Schematic presentation of the cellular events during the multistep angiogenic process. ECs are activated by pro-angiogenic cues, and acquire a tip cell migratory or a stalk cell proliferating identity. ECM is remodelled and new sprouts invade the surrounding environment, form a lumen and connect with other sprouting vessels. The primary vascular plexus matures into a patterned network of arteries, veins and capillaries. Further stabilisation of blood vessels is achieved by association with pericytes and smooth muscle cells and establishment of the basement membrane.

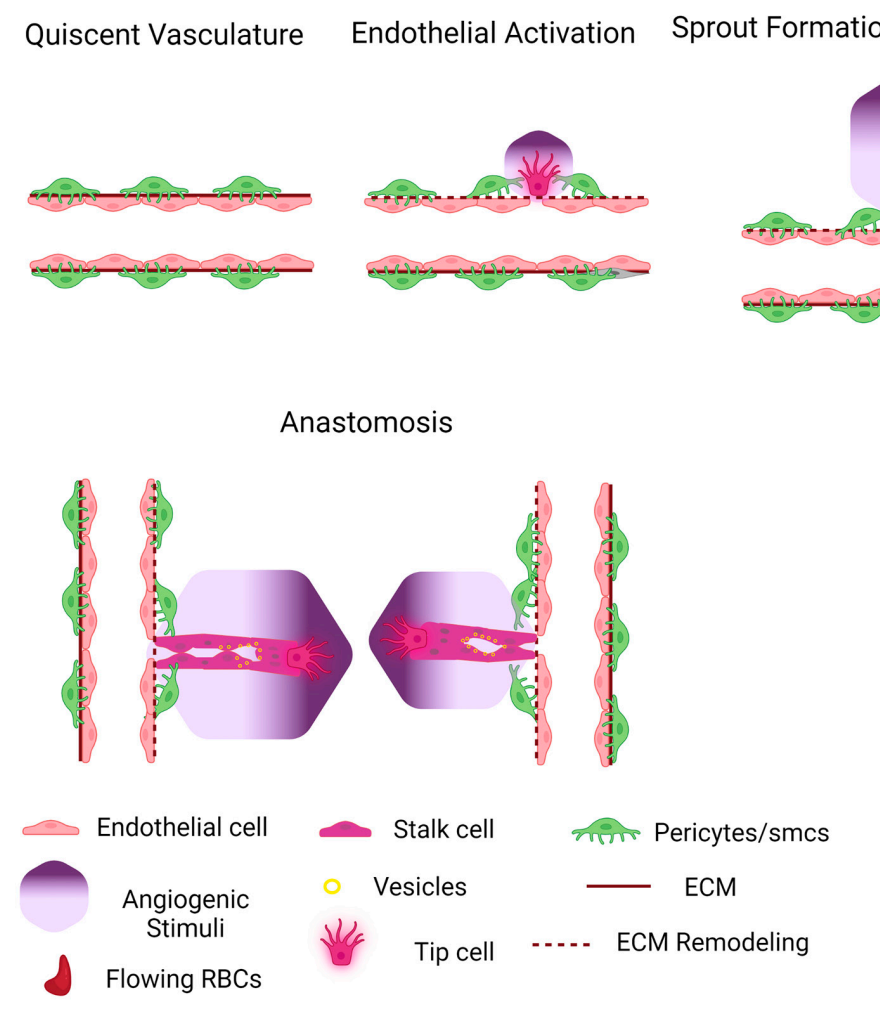

by changes in tissue energy and oxygen demands. In pathological situations such as cancer, EC activation is triggered by a shift in the balance of pro-angiogenic and anti-angiogenic factors that govern vessel homeostasis. The activation of ECs results in extensive remodelling of extracellular matrix and EC differentiation into migrating tip cells and proliferating stalk cells (Potente et al. 2011). Tip cells extend actin-based protrusions called filopodia, to receive and translate the guidance cues of the microenvironment and migrate to form the new sprout. Stalk cells proliferate to provide additional ECs that will expand the sprout. Subsequently, ECs in the extended sprout form the vascular lumen. Different processes have been proposed for lumen formation, including cord hollowing (Iruela-Arispe and Beitel, 2013). During luminisation, ECs establish apical-basal polarity and separate apically at their contact surfaces by fusing intracellular vessels. In a similar process of cell hollowing, ECs generate vacuoles that fuse in the cytoplasm and create an intracellular lumen that expands inside the cell before fusing to the plasma membrane and connecting to a neighbouring intracellular lumen (Betz et al. 2016). Studies in zebrafish unravelled the generation of intracellular lumens by hemodynamic forces that create a plasma membrane invagination that extends towards the cytoplasm of EC. Cell rearrangements and lumen expansion connect adjacent lumens and create a continuous blood-filled channel (Betz et al. 2016).The new sprout eventually fuses with another new sprout (head-to-head sprout anastomosis) or an established vessel (sprout-to-side anastomosis) to enable vessel perfusion and participation in blood circulation (Potente et al. 2011).

\section{Intussusceptive angiogenesis}

The intussusceptive angiogenesis is less understood and the role of cell adhesion is still unclear because of the lack of specific in vivo and in vitro studying models (Nowak-Sliwinska et al. 2018) and the difficulty in visualising and detecting the process in tissues. To date, intussusceptive angiogenesis has been mainly studied in the chicken chorioallantoic membrane (CAM) and in vascular "corrosion" casts from the kidney (Makanya et al. 2009). Intussusception involves the formation of an intraluminal pilar composed of extracellular matrix components in the middle of a dilated vessel that is subsequently divided into two by the action of pericytes and matrix-metalloproteinases (Burri and Djonov, 2002). It is thought to be induced by increased hemodynamic flow and regulated by potent angiogenic factors, such as VEGF and hypoxia. The recent demonstration that intussusception follows angiogenic sprouting in vivo during the development of the zebrafish vasculature (Karthiket al. 2018), and the evidence for the initiation of vessel intussusception after anti-angiogenic treatment to sustain tumour growth, are expected to spark new investigations aiming to clarify the unknown molecular mechanisms driving intussusceptive vascular growth. It would be interesting to delineate the contribution of vascular adhesion in this process.

\section{Vascular patterning}

Following the formation of new blood vessels, blood flow dynamics will fine-tune the newly formed vascular network by processes of pruning and stabilisation (Fig. 1). Newly-formed blood vessels that exhibit very low or no blood flow will regress, while others will stabilise to create a functional network. Vascular remodelling is followed by blood vessel maturation and patterning that allows the hierarchical organisation into arteries, veins and capillaries (Fonseca et al. 2020). Deposition of ECM in the basement membrane and recruitment of mural cells (pericytes and smooth muscle cells) trigger the quiescence of ECs and stabilise the neovessel, safeguarding 
vessel integrity (Potente et al. 2011). Additionally, the expression of specific proteins by ECs generates organ-distinct vascular beds and confersarterial-venous identity.

\section{Tumour neovascularisation}

Since the initial studies of Judah Folkman and his team in 1971 , it is now well-established that tumours are unable to grow and form metastasis without the formation of a vascular network (Folkman, 1971; Potente et al. 2011). Indeed, angiogenesis is a clinical marker for cancer stratification, intimately linked to tumour malignancy. Research advances have moved from a cancer cellcentric focus to the significance of the tumour microenvironment in malignancy and metastasis, opening new avenues for therapeutic interventions. It is well-appreciated the contribution of different types of tumour stromal cells are known to make a significant contribution in cancer progression, where the vascular system is at the central stage, regulating immune cell infiltration, tumour cell survival, proliferation and invasion (Nikolopoulou et al. 2021).Even at pre-malignant stages, an imbalance in growth-stimulating factors and suppressors triggers the "angiogenic switch" and initiates the involvement of the vascular system (Hanahan and Folkman, 1996). In the tumour microenvironment, hypoxia and pro-angiogenic factors secreted by cancer and stromal cells induce mainly sprouting angiogenesis (Potente et al. 2011). Intussusceptive angiogenesis has been reported in certain cancers and as an alternative form of vascular re-growth upon inhibition of angiogenic factors, such as vascular endothelial growth factor (VEGF) (Burri and Djonov, 2002).

\section{Alternative ways of tumour vascularisation}

Aggressive cancers, including melanoma, glioma and lung cancer, also use vascular mimicry to propel their growth. Tumour cells can organise themselves into matrix-rich channels that can be joined to tumour vascular circulation, mimicking blood vessels (Lugano et al. 2019). In a process related to vascular mimicry, tumour cells or cancer stem cells can express on their surface endothelial markers that facilitate their integration into the developing vascular network (Fernández-Cortés et al. 2019). Both vascular mimicry and the acquisition of an endothelial-like phenotype by cancer cells hinder the efficacy of anti-angiogenic treatments.

Furthermore, both at initial tumour formation and later stages in organs rich in blood vessels such as lung and liver, cancer can exploit the normal tissue vascular plexus and progress by vessel co-option. Tumour cells expand in the vicinity of the host vasculature, alongside blood vessels that modify accordingly to support tumour exponential growth and obtain routes for metastasis (Bridgeman et al. 2016; Lugano et al. 2019).

The outcome of the above processes is a highly tortuous, chaotic and disorganised tumour vasculature. The vessels themselves are extremely leaky and the vascular patterning is severely disrupted, giving rise to a dysfunctional network that hinders drug delivery and facilitates metastasis.

\section{Molecular pathways in angiogenesis}

Developmental angiogenesis and tumour neovascularisation have been the focus of extensive research for the past 50 years, leading to the identification of essential growth factors and critical molecular pathways (Potente et al. 2011; Fonseca et al. 2020). For example, the family of VEGF and their receptors (VEGFRs), as well as Notch-Delta signalling, along with other cytokines, angiopoietins, hypoxia-inducible factors (HIF)and WNT/b-catenin signalling, have been shown to regulate many aspects of the angiogenic processes both in physiology and pathology (Potente et al. 2011; Lugano et al. 2019). Many intracellular signal transduction pathways, including phosphoinositide-3-kinase (PI3K), mitogen-activated protein kinases (MAPKs) and protein-tyrosine phosphatases (PTPs), are also critically involved in regulating vascular morphogenesis (Ramjaun and and Hodivala-Dilke 2009; Graupera and Potente 2013; Hale et al. 2017). Blood flow through the function of transcription factors such as KLF2, and the interplay between ECs and perivascular cells through placental derived growth factors (PDGFs) and their receptors (PDGFRs), Angiopoietins, Notch, and Ephrins/EphBs signalling participate in stabilising the neovessels and maintaining vascular homeostasis (Betsholtz, 2018).

Although the biochemical signals that are involved in the formation and maintenance of the vascular system have been studied in depth, the significance of cell adhesion is still relatively unexplored. Both cell-to-cell and cell-to-ECM adhesions need to be remodelled and re-organised to enable cell shape changes, migration, invasion, proliferation and lumen formation, all key angiogenic steps. Emerging data also indicate that vascular patterning is adhesion-dependent and that the subsequent stabilisation of the vascular network relies on direct interactions of ECs with the ECM and perivascular cells (Ramjaun and Hodivala-Dilke 2009; Fonseca et al. 2020). Additionally, it is becoming increasingly evident that, besides chemical cues, the mechanical properties of tissues play a central role in organ physiology and pathology. Indeed, in tumours, it is well-established that the mechanical properties of the tumour microenvironment define both the malignancy and the therapeutic outcome (Mohammadi and Sahai, 2018). More specifically, the tumour vasculature contributes to and is affected by cancer mechanics (Zanotelli and Reinhart-King, 2018).Cell-matrix adhesions act as one of the main mechanical hubs, where the rigidity of the microenvironment and tensional forces are perceived and translated to biochemical signals governing cellular responses (Weinberg et al. 2017).

Since there are many excellent recent reviews on the role of cell-cell junctions in angiogenesis and blood vessel remodelling (Dorland and Huveneers 2016; Claesson-Welsh et al. 2020), here we discuss the current understanding of how endothelial cell-matrix adhesions control vascular development and tumour angiogenesis.

\section{Fundamentals of cell-matrix adhesion}

To delineate the involvement of cell-matrix adhesions in vessel morphogenesis, we will first provide a brief overview of the molecular composition and architecture of cellular adhesions (Fig. 2). Cellmatrix adhesions are highly dynamic structures located basally at the specific sites where the cell interacts with the ECM. They can be classified into different types characterised by distinct morphology, localisation, lifespan and protein composition. Nascent adhesions are the smallest adhesive structures formed at the leading edges of membrane protrusions. They are very short-lived and either mature into focal complexes or dissolve. Focal complexes are also highly dynamic, with a fast turnover, located mainly at the cell periphery. Focal adhesions are more complex and stable structures with a half-life of minutes and can form at both the periphery and central parts of the cell (Gardel et al. 2010). 

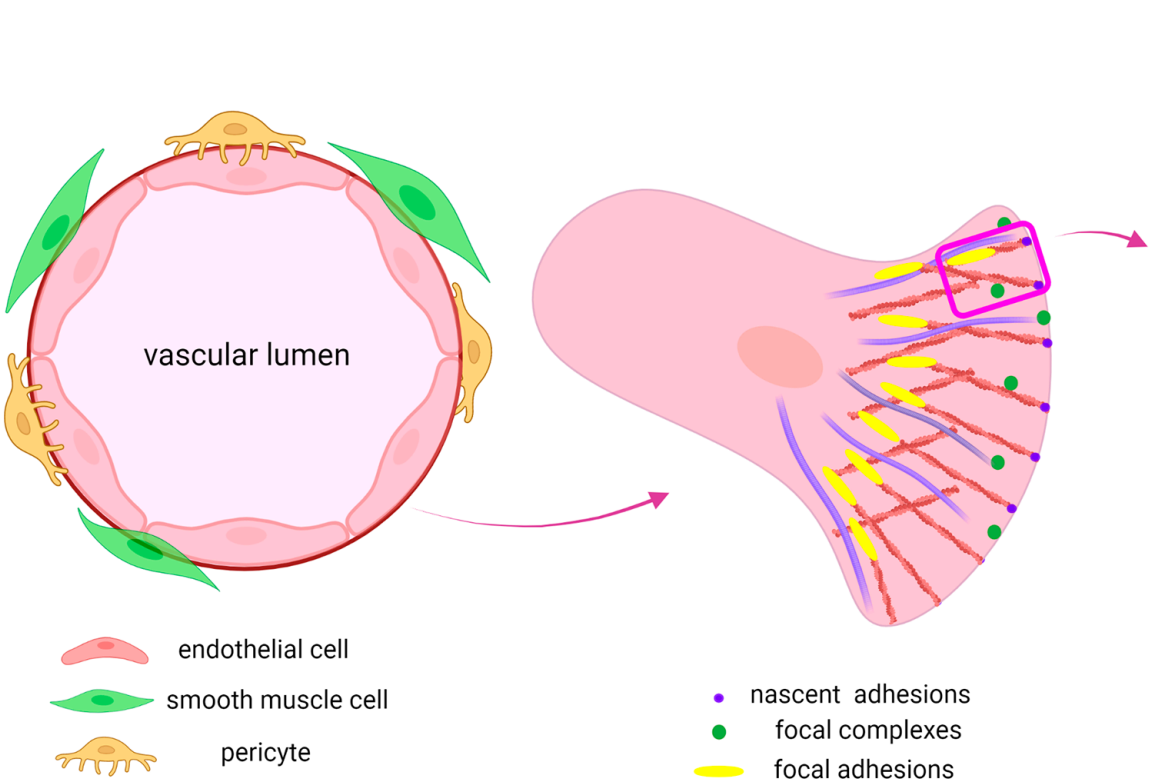

\section{Cell-Matrix adhesion}
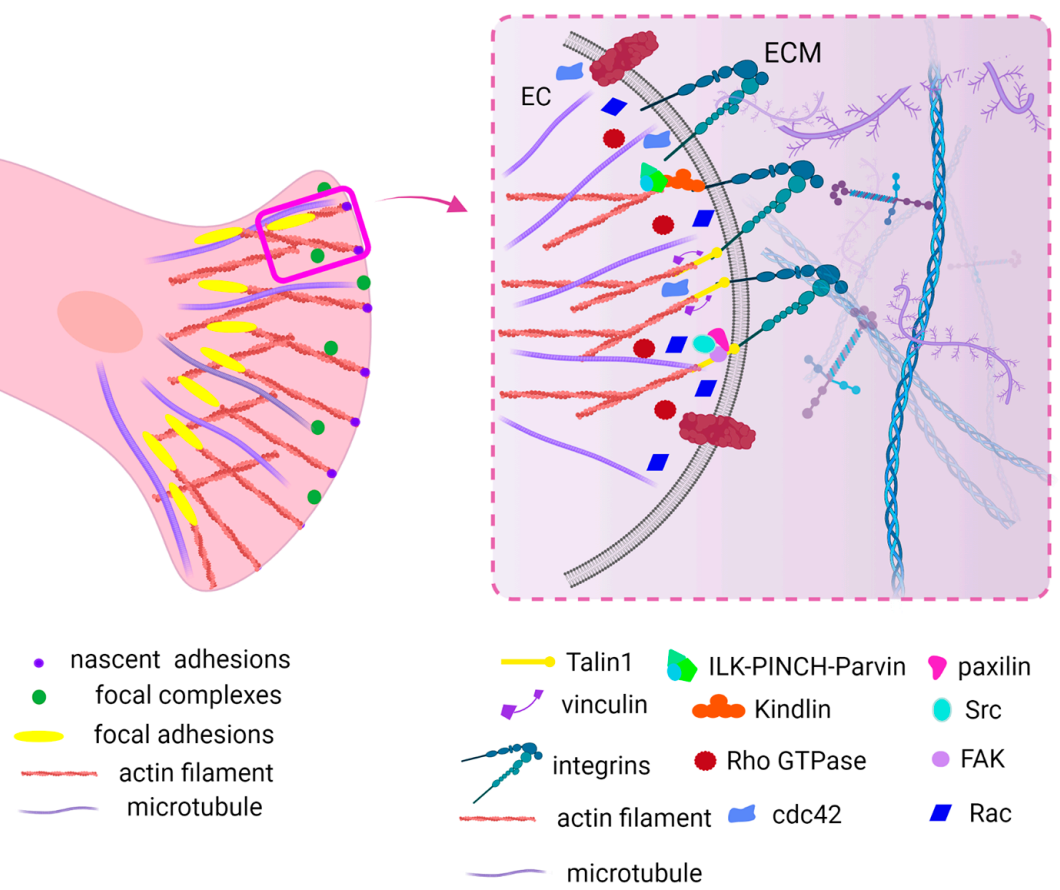

transmembrane receptors

extracellular matrix

Fig. 2. Schematic organisation of blood vessels, cell-matrix adhesions and adhesome members with a known role in angiogenesis. Blood vessels consist of ECs forming a monolayer attached to the basement membrane and surrounding by perivascular cells. During cell migration, membrane protrusions are stabilised by nascent adhesions and focal complexes that further mature in stable focal adhesions. Adhesome is a dynamic network of cytoskeletal signalling and structural proteins that connect integrins to the cell cytoskeleton.

\section{Adhesome}

All types of cell-matrix adhesions have a common structure, consisting of a network of scaffolding and signalling proteins, called "adhesome", which links integrin transmembrane receptors to the cell cytoskeleton. The molecular composition and organisation of the adhesome differ in time and space, making it a highly dynamic network, capable of regulating all-important cellular functions, ranging from cell adhesion and migration to proliferation and differentiation (Zaidel-Bar and Geiger, 2010). Indeed, the adhesome physical anchor cells to the surrounding environment, sense and respond to mechanical cues, and receive signals from growth factors and various molecular pathways, acting as a key integrating hub to orchestrate cellular responses. The adhesome protein network encompasses more than 232 members, including i) the family of integrins cell surface receptors, ii) structural/adaptor proteins: talin, vinculin, ILK-PINCH-parvin, paxillin, zyxin, tensin, KANK, etc), many of which have also a mechanosensing ability (such as talin, vinculin, zyxin, etc) iii) signalling proteins: kinases (such as FAK, Src family, PI3Ks, myosin light chain kinase), phosphatases (PTPs, PTEN, SHP2) and iv) cell cytoskeletal-regulating proteins:Rho GTPase family, and actin-associating proteins, a-actinin, filamin, Arp2/3 etc. These proteins are intrinsic components of cell-matrix adhesions or transiently associate with the adhesion network (Geiger and Yamada, 2011). Furthermore, adhesome proteins facilitate cross-talk between actin structures (stress fibres, cortical actin, lamellipodia, filopodia) and microtubules, to stabilise cell shape and facilitate cellular homeostasis (Horton et al. 2015). Given the critical role of cell-matrix adhesions in regulating cell behaviour, current research focuses on elucidating the requirement of adhesome components in angiogenesis. Here, we discuss evidence that supports the important role of adhesome proteins in the regulation of developmental and tumour angiogenesis.

\section{Cell-matrix adhesions and developmental angiogenesis}

Distinct approaches, including global and EC-specific genetic deletions, various cellular assays and inhibition studies have revealed the critical involvement of adhesome components in all steps of blood vessel formation. Many angiogenic studies have focused on the role of integrin cell-surface receptors that directly interact with various ECM components (Avraamides et al. 2008). Integrins are heterodimers composed of an $\alpha$ and a $\beta$ subunit. From the 24 unique combinations of $\alpha$ and $\beta$ pairs, EC expresses $\alpha 1 \beta 1, \alpha 2 \beta 1$, $a 3 \beta 1, a 4 \beta 1, a 5 \beta 1, a 6 \beta 1, a 9 \beta 1, a v \beta 3, a v \beta 5$, which can bind, among other ECM components, collagens, laminins and fibronectins, found in the basement membrane and the provisional matrix of blood vessels (Hynes, 2002). Many integrins, such as a6 $\beta 1, a 5 \beta 1$ and $\operatorname{av} \beta 3$, are upregulated in angiogenic endothelium, suggesting 
a major role in angiogenesis (Niland and Eble, 2012). Consistent with this, genetic deletion of integrin $\beta 1$, the most common subunit of integrin dimers, specifically in ECs, led to embryonic lethality at embryonic date(E)9.5-E10.5 with severe vascular defects, indicating an important function of integrins in developmental angiogenesis (Carlson et al. 2008; Lei et al. 2008; Tanjore et al. 2008). Nevertheless, global genetic deletions of the majority of integrin a subunits, including av, a1, a2, a4, a3, and a6, although they affect the viability of the embryo because of defects in other organs, do not impede the formation of embryonic blood vessels (Niland and Eble, 2012). These findings suggest redundant and compensatory functions of different integrins during embryonic angiogenesis. A striking exception is the case of integrin a5. Mice with global genetic ablation of integrin a5 die at E10-11 with defective vascular development of the yolk sac and the embryo proper, indicating an essential function for this integrin in physiological angiogenesis (Yang et al. 1993; Francis et al. 2002). Other integrins, like integrin $\alpha 9 \beta 1$, are highly expressed in lymphatic endothelial cells and have a role in lymphangiogenesis without affecting blood vessel development (Huang et al. 2000; Bazigou et al. 2011).

Although it is difficult to separate the involvement of integrins in embryonic angiogenesis from their developmental role in other organs, there is genetic evidence for the requirement of integrinassociated proteins in physiological angiogenesis. For example, talin binds directly to integrins and is required for integrin activation and clustering (Critchley and Gingras, 2008). Endothelial deletion of talin1 results in early embryonic lethality due to vascular defects (Monkley et al. 2011). Similarly, integrin-linked kinase (ILK) has a major role in embryonic blood vessel development, through regulation of EC survival and co-ordination of angiogenic growth factor signalling (Friedrich et al. 2004; Malan et al. 2013). ILK is found in mammalian cells in complex with particularly interesting new cysteine-histidine-rich protein (PINCH) and parvin family proteins, $\alpha$ - and $\beta$ - parvins. Whereas the vascular role of $\mathrm{PINCH}$ is unknown, endothelial deletion of both $\alpha$ - and $\beta$ - parvins led to embryonic lethality at E11.5 with abnormal vascular network formation (Pitter et al. 2018).

Furthermore, a wealth of evidence supports a vital role for integrin-mediating signalling in developmental angiogenesis, with focal adhesion kinase (FAK) being a key player. Endothelial deletion of FAK impaired EC proliferation and migration, causing severe vascular defects, haemorrhaging and embryonic lethality by E11.5 (Shen et al. 2005; Braren et al. 2006). Interestingly, the kinase function of FAK was required for EC migration and cell-cell junctional stability but not EC survival, since an endothelial-specific knock-in mouse expressing kinase-deficient FAK displayed no apoptotic defects. However, these mice also died at E13.5 due to defective angiogenesis and vascular barrier function (Zhao et al. 2010). Taken together, these findings demonstrate kinase-dependent and -independent functions of FAK, highlighting the importance of thorough analysis of FAK function in the entire organism.

Besides structural and signalling adhesome components, the connection to the cell cytoskeleton is a key function of cell-matrix adhesions. Regulation of actin cytoskeleton by the Rho-GTPases family is essential for organising cell morphology and cell migration, and is thus involved in angiogenic processes. Although endothelial deletion of RhoA-GTPase exhibits normal blood vessel development, other members of the Rho-family affected embryonic angiogenesis (Zahra et al. 2019). Specifically, genetic studies demonstrated that cdc42 is required for EC survival and embryonic angiogenesis (Jin et al. 2013; Barry et al. 2015). Furthermore, early endothelial deletion of Rac-1 led to embryonic lethality by E9.5 and reduced vessel formation, whereas, loss of endothelial Rac at later stages of embryonic development caused defects in lymphatic-blood vessel separation and subsequent embryonic lethality (Tan et al. 2008; D'Amico et al. 2009).

\section{Cell-matrix adhesions and EC migration}

Cell migration is a highly coordinated action of cell-matrix adhesion re-arrangements and cell cytoskeletal remodelling. Actin polymerisation drives membrane extensions in the form of filopodia and lamellipodia that are stabilised by the formation of nascent adhesions and focal complexes (Fig. 2). Stable focal adhesions are re-organised or resolved, and actomyosin contractility generates appropriate tension to facilitate the translocation of the cell body. During angiogenesis, ECs migrate to generate the new vessel. Furthermore, endothelial tip cells extend filopodia protrusions to explore the angiogenic microenvironment and migrate along with the stalk cells to form the new sprout. Therefore, it is evident that adhesome members will have a central role in this process. Indeed, reduction in cell migration, along with decreased cell survival, is the main reason for developmental angiogenic defects and embryonic lethality. Various experimental approaches, ranging from in vitro cell migration and invasion assays, ex vivo aortic ring assays to in vivo models of vessel formation in zebrafish and the postnatal development of retina vasculature, have shed light on the requirement of specific adhesome members for angiogenic sprouting.

Indeed, cell migration is impaired in mice lacking endothelial expression of integrin $\beta 1$, and integrin a5 is upregulated in angiogenic endothelium and activates intracellular signalling pathways to enhance EC migration (Francis et al. 2002; Carlson et al. 2008). Similarly, ILK regulates EC spreading, migration and capillary formation in response to VEGF and FGF angiogenic factors (Tan et al. 2004; Vouret-Craviari et al. 2004; Malan et al. 2013). Loss of ECILK function in the developing retina severely impaired angiogenic sprouting, decreased vessel branching and compromised endothelial tip cell invasion and deeper vascular layer formation (Park et al. 2019). Defective lamellipodia formation, cell spreading and migration also exhibit ECs completely deficient in FAK expression, whereas increased migration is observed in FAK heterozygous EC, which express half the amount of FAK (Braren et al. 2006;Tavora et al. 2010; Kostourou et al. 2013). Detailed examination of the developing retina vasculature in mice with inducible endothelial deletion of FAK postnatally revealed decreased angiogenic sprouting without affecting endothelial tip cell specification (Tavora et al. 2010). Similarly, defective sprout formation and radial outgrowth of the retina vasculature was observed in mice lacking endothelial expression of other key adhesome members, including talin, vinculin, and parvin. In addition to the defective migration during the superficial retinal layer, ECs deficient for these proteins were unable to sprout perpendicularly and invade the deeper retina to form other capillary layers (Fraccaroli et al. 2015; Carvalho et al. 2019; Pulous et al. 2020). Remarkably, EC tip selection was unaffected and filopodia were present, albeit in aberrant numbers, suggesting compromised cell-matrix adhesion re-organisation rather than defects in cytoskeletal remodelling.Changes in cellmatrix adhesions, however, are strictly controlled, as exemplified 
by studies of paxillin, an intrinsic adhesome component. Paxillin can regulate adhesion assembly and disassembly, along with RhoGTPase dynamics (Nishiya et al. 2005). Depletion of endothelial paxillin, using siRNA, increased EC migration and invasion and caused excessive angiogenic sprouting in the developing retina vasculature by interfering with growth factor signalling (German et al. 2014).

Genetic studies of Rho-family GTPases have also highlighted the central role of actin regulation in EC migration and vessel formation. Endothelial cdc42 deletion postnatally reduced EC filopodia formation and migration during retinal sprouting angiogenesis (Barry et al. 2015). Lack of lamellipodia formation and reduced EC motility in response to pro-migratory stimuli is also observed in Rac1 deficient ECs (Tan et al. 2008).In developing retina vasculature, endothelial deletion of Rac1 decreased vessel branching and EC invasion necessary to form the deeper plexus (Nohata et al. 2016). Moreover, deletion of the endothelial-specific RhoJ impaired EC migration and reduced vessel branching and sprouting angiogenesis in the retina, by interfering with a5 integrin trafficking, further supporting the functional link of cell-matrix adhesions with cell cytoskeleton (Fukushima et al. 2020; Sundararaman et al. 2020).

\section{Cell-matrix adhesions and lumen formation}

The formation of the endothelial lumen is essential for vascular morphogenesis, and involves re-arrangement of stalk cells and changes in EC polarity, contractility and shape. The successful completion of these steps requires the remodelling of both cell adhesions and the actin cytoskeleton. It is not surprising, therefore, that integrins and Rho-GTPases have been shown to regulate vessel lumenisation. Initial studies culturing human umbilical vein endothelial cells (HUVECs) in a 3D matrix revealed the formation of lumens from the coalescence of intracellular vacuoles.Using integrin inhibitors, it was shown that both fibronectin-binding integrins such as $\alpha v \beta 3$ and $a 5 \beta 1$ and collagen-binding integrins such as a2 $\beta 1$ participate in lumen formation (Davis and Camarillo 1996; Bayless et al. 2000). In the same 3D cellular system, the significant role of Rac1 and cdc42 small GTPases in vacuole coalescence and lumen expansion was revealed, using dominant-negative forms of these proteins (Bayless and Davis, 2002). Similarly, knockdown of RhoJ decreased lumen formation by downregulating Rac1 and cdc42 activity and upregulated RhoA (Yuan et al. 2011).

However, direct evidence of the involvement of integrins and Rho-GTPases in vascular lumen formation was attained much later from in vivo studies. Endothelial-specific deletion of cdc42, and mosaic gene ablation studies in the developing retina, all confirm a central role of cdc42 in controlling vascular lumen formation by regulating apical-basal and axial polarity (Barry et al. 2015; Laviña et al. 2018). Regulation of small Rho GTPases, Rac 1 and cdc 42 by Ras interacting protein 1 (Rasip1) and Arhgap 29 were also required for lumenisation in the mouse embryo (Xu et al. 2011). Further studies demonstrated that Rasip1 regulates locally cdc42 and actomyosin contractility to reorganise adherens junctions and induce apical membrane separation and lumen formation (Barry et al. 2016).

The zebrafish has also proven to be a very useful model to study lumen formation in real-time. Visualisation of lumen formation in zebrafish intersomitic vessels evidenced the contribution of blood flow in the process of cell and cord hollowing. Forces from blood flow deform the EC membrane to create inverse blebs that develop into transcellular invaginations. Subsequent studies revealed that actin polymerising and bundling proteins such as formins and myristoylated alanine-rich C-kinase substrate like 1 (MARCKSL1) respectively, reorganise actin and regulate lumen formation and expansion (Phng et al. 2015; Kondrychyn et al. 2020).

Exploiting an inducible endothelial-specific system that deleted integrin $\beta 1$ later in embryonic development, it was demonstrated that integrin $\beta 1$ plays a critical role in the apical-basal polarisation of ECs by controlling Par-3 localisation (Zovein et al. 2010). The significant contribution of core adhesome members in lumen formation is poorly defined. The major vascular defects caused by the elimination of the function of key adhesome members poses a significant challenge when ascertaining their contribution to EC migration and survival versus lumen formation. Further genetic tools and cellular assays will need to be developed to shed light on the molecular mechanisms governing vessel lumenisation and vascular morphogenesis.

\section{Cell-matrix adhesions and vascular patterning}

Following the formation of the initial network by sprouting anastomosis, angiogenic remodelling will define an optimised vascular plexus with a hierarchical organisation of arteries, veins and capillaries. New vascular branches will be stabilised and others will regress. Hemodynamic forces generated by blood flow often determine which vessel connections are strengthened and which are removed. Superfluous vascular structures are pruned by a tightly regulated process that does not involve EC apoptosis but rather cell movement (Franco et al. 2015). It has been proposed that ECs polarise axially (front to rare) against the direction of blood flow and migrate away from regions with low or no flow. The mechanisms regulating these movements are not well understood. The axial polarisation of ECs and the re-organisation of AJs to facilitate collective cell migration are thought to be involved (Fonseca et al. 2020). Several molecular pathways have been implicated, including non-canonical wnt signalling, sphingosine 1-phosphate S1P and its receptor S1PR1 along with signalling effectors such as PI3K, small RhoGTPases and actomyosin contractility (Fonseca et al. 2020).

Studies using mice with heterozygous integrin $\beta 1$ endothelial deletion that display $40 \%$ of integrin $\beta 1$ expression in ECs have abnormal vascular remodelling responses to blood flow, suggesting a role of this integrin in vascular patterning (Lei et al. 2008). Reduced vascular density is also a common phenotype of many adhesome -deficient vasculatures, including integrin a5, ILK, talin, parvin (Francis et al. 2002; Monkley et al. 2011; Park et al. 2019; Pitter et al. 2018). Similarly, endothelial deletion of FAK or expression of FAK defective in the kinase activity or phosphorylation on tyrosine-397 (FAK-Y397F) exhibit reduced vessel density and abnormal vascular remodelling (Corsi et al. 2009; Lim et al. 2010; Tavora et al. 2010). However, it is difficult to discern whether the reduced vessel density is caused by decreased development of vascular branches or increased regression of newly formed vessels. Interestingly, vinculin, an adhesome component that is localised both at cell-matrix and adherens junctions, is involved in vessel pruning. Mice with endothelial deletion of vinculin develop normally with no obvious embryonic vascular defects. Detailed examination of the retina vasculature in these mice showed reduced radial outgrowth and increased numbers of regressing vessels because of defects in collective EC polarity (Carvalho et al. 2019). 


\section{Cell-matrix adhesions and vessel maturation}

Vessel regression is also associated with vessel instability due to defective vascular maturation. Recruitment and association of perivascular cells, namely pericytes and smooth muscle cells, and the establishment of a quiescent ECM that comprise the vascular basement membrane, are both critical for the stability of blood vessels. RhoJ participate in vessel maturation by regulating the deposition of fibronectin around new blood vessels (Sundararaman et al. 2020). Although integrins are involved in organising the ECM, the role of adhesome members in the remodelling of vascular basement membrane remains elusive.

Haemorrhaging and oedema are common manifestations of defective sprouting angiogenesis caused by adhesome members; whether they are associated with reduced pericyte coverage is not always explored. Therefore, little evidence exists regarding the role of endothelial cell-matrix adhesions in mediating ECperivascular cell interactions during developmental angiogenesis. Endothelial expressing integrin $\alpha 4 \beta 1$ has been shown to mediate EC-perivascular cell interactions by binding to VCAM1-expressing smooth muscle cells (Garmy-Susini et al. 2005). Furthermore, besides the sprouting defects caused by endothelial deletion of a-parvin, newly formed embryonic blood vessels also displayed impaired coverage by smooth muscle cells (Montanez et al. 2009). Similarly, heterozygous mice for kindlin2, an integrin-associated protein, exhibited thinner vascular basement membrane and reduced pericyte coverage, leading to vessel instability and leakage (Pluskota et al. 2011). Further studies are required to decipher how adhesome components regulate cellular interaction during vascular morphogenesis.

\section{Cell-matrix adhesions and tumour angiogenesis}

Despite the pivotal role of cell-matrix adhesions in cancer cell motility and survival, the significance of endothelial adhesome in tumour neovascularisation remains largely unexplored (Nikolopoulou et al. 2021). Genetic deletion approaches and inhibitor studies have been used to delineate the contribution of integrins in tumour angiogenesis. In contrast to normal vascular development, mice deficient in many integrin subunits, including a1, $\alpha 2, a 3, a 6, \beta 4, a v \beta 3$, exhibit aberrant and opposing angiogenic responses in cancer. For example, endothelial deletion of integrin a3 did not impact embryonic vascularisation but increased tumour growth and angiogenesis in the adult mice by regulating VEGFR2 function (da Silva et al. 2010). Conversely, antagonists of integrin a $4 \beta 1$ blocked tumour growth and angiogenesis (Garmy-Susini et al. 2005). Cellular studies using antibody inhibitors or small interfering RNA for integrin a6 showed impaired EC migration and tube formation, in vitro (Lee et al. 2006). Global genetic deletion of integrin $\beta 4$ subunit, which form a dimer with integrin a6 subunit, decreased postnatal angiogenesis and tumour neovascularisation (Nikolopoulos et al. 2004). Contrary to these studies, endothelial-specific ablation of integrin a 6 increased tumour growth and angiogenesis, suggesting that integrin a6 is not a good target for anti-angiogenic therapies (Germain et al. 2010). Furthermore, some integrins, although they share the same ECM ligand, differentially regulate tumour angiogenesis, as exemplified by the collagen-binding integrins $\alpha 1 \beta 1$ and $\alpha 2 \beta 1$. Mice deficient in integrin a1 display reduced tumour angiogenesis, while mice deficient for integrin a2 exhibit increased tumour angiogenesis (Pozzi et al. 2000; Zhang et al. 2008). These contrasting effects could be explained by cross-regulation of integrin subunits, which has been described for many integrin pairs. Integrin av $\beta 3$ is poorly expressed in quiescent ECs and is upregulated in tumour endothelium, making it an interesting therapeutic target. Indeed, pharmacological inhibition of integrin av $\beta 3$ decreased tumour angiogenesis (Brooks et al. 1995). Similarly, mice expressing integrin $\beta 3$ deficient in the phosphorylation of its cytoplasmic tail exhibited impaired tumour angiogenesis (Mahabeleshwar et al. 2006). In contrast, genetic deletion of integrin $\beta 3$ increased tumour angiogenesis and growth (Reynolds et al. 2002). Accordingly, low concentrations of RGDmimetics binding at the ectodomain of integrin av $\beta 3$ increased tumour angiogenesis (Reynolds et al. 2009). Taken together, these studies suggest that inhibition of integrin $\beta 3$ is context-dependent and therefore targeting the ectodomain of integrin $\beta 3$ may not be an effective therapeutic approach. Consistent with the embryonic studies, integrin a5 $\beta 1$ is upregulated in activated ECs during tumour angiogenesis and antagonists for a5 $\beta 1$ impaired tumour growth and neovascularisation (Kim et al. 2000). Furthermore, regulation of integrin activation by talin has been suggested to affect tumour development and angiogenesis (Pulous et al. 2020). The role of another regulator of integrin, kindlin2 in cancer, was studied using heterozygous mice. Prostate tumours grew less efficiently and displayed reduced vessel density in these mice compared with control littermates (Pluskota et al. 2011).

Besides integrins, the contribution of FAK in tumour angiogenesis has been the focus of intensive research, and inhibitors of FAK have participated in clinical trials. According to its important function in developmental angiogenesis, pharmacological inhibition of FAK or inducible endothelial deletion of FAK impeded tumour growth and angiogenesis by inhibiting EC migration and proliferation and enhancing EC apoptosis (Tavora et al. 2010; Nikolopoulou et al. 2021). Furthermore, in a glioma tumour model, endothelial deletion of FAK, impaired tumour growth by decreasing tumour vessel diameter and increasing EC barrier function (Lee et al. 2010). FAK heterozygous mice, however, which express reduced levels of FAK, or suboptimal FAK inhibition, increased tumour formation and angiogenesis, indicating a dose-dependent effect of FAK inhibition and calling for a thorough characterisation of FAK function before clinical application (Kostourou et al. 2013). Accordingly, several functional domains of FAK - including the FAK kinase domain, the autophosphorylation tyrosine site Y397 (blocking Y397F or mimic Y397E phosphorylation), and the Src-phosphorylation site Y861 (blocking Y861F) - have been targeted, and the corresponding ECspecific mutant mice have been used in tumour studies (Tavora et al. 2014). These studies revealed that both the FAK kinase activity and the autophosphorylation site promote tumour angiogenesis and vascular leakage, facilitating cancer growth and metastasis (Alexopoulou et al. 2017; Pedrosa et al. 2019). The requirement of FAK-phosphorylation at tyrosine -861 is context-dependent, with early stages of tumour development being more susceptible than established tumours. Although these findings suggest that a delicate balance of FAK regulation is a prerequisite for anti-angiogenic therapy, recent studies have unravelled a paracrine role of FAK in sensitising tumours to DNA-damaging agents, opening new avenues for combinatorial anticancer treatment (Nikolopoulou et al. 2021).

Consistent with an essential function of ILK in developmental angiogenesis, pharmacological inhibition of ILK decreased tumour 
growth and vessel density by inducing apoptosis in both ECs and tumour cells (Nikolopoulou et al. 2021). Similarly, siRNA depletion of ILK in prostate cancer impaired tumour growth and angiogenesis by inhibiting hypoxia-driven VEGF expression (Tan et al. 2004). In a pancreatic cancer model, however, pharmacological inhibition of ILK impeded tumour development without affecting tumour angiogenesis (Yau et al. 2005). Genetic studies of endothelialspecific ILK deletion are necessary to ascertain cancer-intrinsic versus angiogenic effects of ILK in cancer development.

The impact of actin regulation in tumour angiogenesis has been explored in mice deficient in RhoJ. Both global and endothelialspecific deletion of RhoJ disrupted tumour blood vessel formation and integrity, resulting in impaired cancer growth. Similar defective tumour angiogenesis and growth was observed following siRNA -mediated depletion of Rac1 from the whole tumour environment (Nikolopoulou et al. 2021). However, specifically targeting Rac1 in tumour endothelial cells did not affect tumour growth and angiogenesis in wild-type mice but restricted the elevated tumour development and neovascularisation induced by integrin- $\beta 3$ deficiency (D'Amico et al. 2010).

\section{Concluding Remarks}

A wealth of studies has advanced our knowledge of the cellular events and the molecular pathways that regulate angiogenesis. While the contribution of growth factors and Notch signalling has been established, we still lack a good understanding of the key players and the signals controlling the different angiogenic steps during development and in cancer. Questions still have to be answered regarding the molecular events regulating vascular lumen formation, remodelling and patterning. Furthermore, what is becoming increasingly evident is the involvement of mechanical forces derived from blood flow and the rigidity of the basement membrane in determining blood vessel formation and function. Cell-matrix adhesions, although understudied, have emerged as critical regulators of angiogenesis, as discussed in this review. Besides controlling cell migration and proliferation, we still lack sufficient understanding of the impact of adhesome members in other steps of the angiogenic process. Given that cell-matrix adhesions present the main hub for cell mechanotransduction, it is envisaged that adhesome members critically determine blood vessel responses to mechanical cues and control every angiogenic step. Most importantly, our understanding of blood vessel development in cancer is limited to sprouting angiogenesis. Next to nothing is known about the signals regulating intussusception, vessel co-option and mimicry, and the role of endothelial cell-matrix adhesions have not yet been explored. The latter is particularly important for the efficient therapeutic manipulation of angiogenesis and the development of novel anti-cancer therapies.

\section{Acknowledgments}

Figures were prepared using BioRender (https://biorender.com/). This research was funded by "A Greek Research Infrastructure for Visualizing and Monitoring Fundamental Biological Processes (BIO- IMAGINGGR)" (MIS 5002755), implemented under the Action "Reinforcement of the Research and Innovation Infrastructure", funded by the Operational Programme "Competitiveness, Entrepreneurship and Innovation" (NSRF 2014-2020) and co-financed by Greece and the European Union (European Regional Development Fund) and "The Hellenic Foundation for Research and Innovation (H.F.R.I.) under the "First Call for H.F.R.I. Re- search Projects to support Faculty members and Researchers and the procurement of high-cost research equipment grant" (Project Number: HFRI-FM17-2644)". GR is funded by State Scholarships Foundation cofinanced by Greece and the European Union (European Social Fund- ESF) through the Operational Programme «Human Resources Development, Education and Lifelong Learning" in the context of the project "Strengthening Human Resources Research Potential via Doctorate Research" (MIS5000432), implemented by the State Scholarships Foundation (IKY).

\section{References}

ALEXOPOULOU A. N., LEES D. M., BODRUG N., LECHERTIER T., FERNANDEZ I., D'AMICO G., DUKINFIELD M., BATISTA S., TAVORA B., SERRELS B., HODIVALADILKE K. (2017). Focal Adhesion Kinase (FAK) tyrosine 397E mutation restores the vascular leakage defect in endothelium-specific FAK-kinase dead mice. The Journal of Pathology 242: 358-370. https://doi.org/10.1002/path.4911

AVRAAMIDES C. J., GARMY-SUSINI B., VARNER J. A. (2008). Integrins in angiogenesis and lymphangiogenesis. Nature Reviews Cancer 8: 604-617. https://doi. org/10.1038/nrc2353

BARRY D. M., KOO Y., NORDEN P. R., WYLIE L. A., XU K., WICHAIDIT C., AZIZOGLU D. B., ZHENG Y., COBB M. H., DAVIS G. E., CLEAVER O. (2016). Rasip1-Mediated Rho GTPase Signaling Regulates Blood Vessel Tubulogenesis via Nonmuscle Myosin II. Circulation Research 119: 810-826. https://doi.org/10.1161/CIRCRESAHA.116.309094

BARRY D. M., XU K., MEADOWS S. M., ZHENG Y., NORDEN P. R., DAVIS G. E., CLEAVER O. (2015). Cdc42 is required for cytoskeletal support of endothelial cell adhesion during blood vessel formation in mice. Development 142: 3058-3070. https://doi.org/10.1242/dev.125260

BAYLESS K. J., DAVIS G. E. (2002). The Cdc42 and Rac1 GTPases are required for capillary lumen formation in three-dimensional extracellular matrices. Journal of Cell Science 115: 1123-1136. https://doi.org/10.1242/jcs.115.6.1123

BAYLESS K. J., SALAZAR R., DAVIS G. E. (2000). RGD-Dependent Vacuolation and Lumen Formation Observed during Endothelial Cell Morphogenesis in Three-Dimensional Fibrin Matrices Involves the av $\beta 3$ and a5 $\beta 1$ Integrins. The American Journal of Pathology 156: 1673-1683. https://doi.org/10.1016/S0002-9440(10)65038-9

BAZIGOU E., LYONS O. T.A., SMITH A., VENN G. E., COPE C., BROWN N. A., MAKINEN T. (2011). Genes regulating lymphangiogenesis control venous valve formation and maintenance in mice. Journal of Clinical Investigation 121:2984-2992. https:// doi.org/10.1172/JCI58050

BETSHOLTZ C. (2018). Cell-cell signaling in blood vessel development and function. EMBO Molecular Medicine 10: 1-4. https://doi.org/10.15252/emmm.201708610

BETZC., LENARD A., BELTING H.G., AFFOLTER M. (2016). Cell behaviors and dynamics during angiogenesis. Development 143: 2249-2260. https://doi.org/10.1242/ dev. 135616

BRAREN R., HU H., KIM Y. H., BEGGS H. E., REICHARDT L. F., WANG R. (2006) Endothelial FAK is essential for vascular network stability, cell survival, and lamellipodial formation. Journal of Cell Biology 172: 151-162. https://doi.org/10.1083/ jcb.200506184

BRIDGEMAN V. L., VERMEULEN P. B., FOO S., BILECZ A., DALEY F., KOSTARAS E., NATHAN M. R., WAN E., FRENTZAS S., SCHWEIGER T., HEGEDUS B., HOETZENECKER K., RENYI-VAMOS F., KUCZYNSKI E. A., VASUDEV N. S., LARKIN J., GORE M., DVORAK H. F., PAKU S., KERBEL R. S., DOME B., REYNOLDS A. R. (2016). Vessel co-option is common in human lung metastases and mediates resistance to anti-angiogenic therapy in preclinical lung metastasis models. The Journal of Pathology 241: 362-374. https://doi.org/10.1002/path.4845

BROOKS P. C., STRÖMBLAD S., KLEMKE R., VISSCHER D., SARKAR F. H., CHERESH D. A. (1995). Antiintegrin alpha v beta 3 blocks human breast cancer growth and angiogenesis in human skin. Journal of Clinical Investigation 96: 1815-1822. https://doi.org/10.1172/JCl118227

BURRI P. H., DJONOV V. (2002). Intussusceptive angiogenesis--the alternative to capillary sprouting. Molecular Aspects of Medicine 23: 1-27. https://doi. org/10.1016/S0098-2997(02)00096-1

CARLSON T. R., HU H., BRAREN R., KIM Y. H., WANG R. A. (2008). Cell-autonomous requirement for $\beta 1$ integrin in endothelial cell adhesion, migration and survival during angiogenesis in mice. Development 135: 2193-2202. https://doi.org/10.1242/ dev.016378 
CARVALHO J. R., FORTUNATO I. C., FONSECA C. G., PEZZAROSSA A., BARBACENA P., DOMINGUEZ-CEJUDO M. A., VASCONCELOS F. F., SANTOS N. C., CARVALHO F. A., FRANCO C. A. (2019). Non-canonical Wnt signaling regulates junctional mechanocoupling during angiogenic collective cell migration. eLife 8: 197. https://doi.org/10.7554/eLife.45853

CLAESSON-WELSH L., DEJANA E., MCDONALD D. M. (2020). Permeability of the Endothelial Barrier: Identifying and Reconciling Controversies. Trends in Molecular Medicine 27: 314-331. https://doi.org/10.1016/j.molmed.2020.11.006

CORSI J.M., HOUBRON C., BILLUART P., BRUNET I., BOUVRÉE K., EICHMANN A., GIRAULT J.A., ENSLEN H. (2009). Autophosphorylation-independent and -dependent Functions of Focal Adhesion Kinase during Development. Journal of Biological Chemistry 284: 34769-34776. https://doi.org/10.1074/jbc.M109.067280

CRITCHLEY D. R., GINGRAS A. R. (2008). Talin at a glance. Journal of Cell Science 121: 1345-1347. https://doi.org/10.1242/jcs.018085

D'AMICO G., JONES D. T., NYE E., SAPIENZA K., RAMJUAN A. R., REYNOLDS L. E., ROBINSON S. D., KOSTOUROUV., MARTINEZ D., AUBYN D., GROSE R., THOMAS G. J., SPENCER-DENE B., ZICHA D., DAVIES D., TYBULEWICZ V., HODIVALADILKE K. M. (2009). Regulation of lymphatic-blood vessel separation by endothelial Rac1. Development 136: 4043-4053. https://doi.org/10.1242/dev.035014

D'AMICO G., ROBINSON S. D., GERMAIN M., REYNOLDS L. E., THOMAS G. J., ELIA G., SAUNDERS G., FRUTTIGER M., TYBULEWICZ V., MAVRIA G., HODIVALADILKE K. M. (2010). Endothelial-Rac1 Is Not Required for Tumor Angiogenesis unless avß3-Integrin Is Absent. PLOS ONE 5: e9766. https://doi.org/10.1371/ journal.pone.0009766

DA SILVA R. G., TAVORA B., ROBINSON S. D., REYNOLDS L. E., SZEKERES C., LAMAR J., BATISTA S., KOSTOUROU V., GERMAIN M. A., REYNOLDS A. R., JONES D. T., WATSON A. R., JONES J. L., HARRIS A., HART I. R., IRUELAARISPE M. L., DIPERSIO C. M., KREIDBERG J. A., HODIVALA-DILKE K. M. (2010). Endothelial a3 $\beta 1$-Integrin Represses Pathological Angiogenesis and Sustains Endothelial-VEGF. The American Journal of Pathology 177: 1534-1548. https://doi.org/10.2353/ajpath.2010.100043

DAVIS G. E., CAMARILLO C. W. (1996). An a2 31 Integrin-Dependent Pinocytic Mechanism Involving Intracellular Vacuole Formation and Coalescence Regulates Capillary Lumen and Tube Formation in Three-Dimensional Collagen Matrix. Experimental Cell Research 224:39-51. https://doi.org/10.1006/excr.1996.0109

DORLAND Y. L., HUVENEERS S. (2016). Cell-cell junctional mechanotransduction in endothelial remodeling. Cellular and Molecular Life Sciences 74: 279-292. https://doi.org/10.1007/s00018-016-2325-8

FERNÁNDEZ-CORTÉS M., DELGADO-BELLIDO D., OLIVER F. J. (2019). Vasculogenic Mimicry: Become an Endothelial Cell "But Not So Much". Frontiers in Oncology 9: 803. https://doi.org/10.3389/fonc.2019.00803

FOLKMAN J. (1971). Tumor Angiogenesis: Therapeutic Implications. New England Journal of Medicine 285: 1182-1186. https://doi.org/10.1056/ NEJM197111182852108

FONSECA C. G., BARBACENA P., FRANCO C. A. (2020). Endothelial cells on the move: dynamics in vascular morphogenesis and disease. Vascular Biology 2: H29-H43. https://doi.org/10.1530/VB-20-0007

FRACCAROLI A., PITTER B., TAHA A. A., SEEBACH J., HUVENEERS S., KIRSCH J., CASAROLI-MARANO R. P., ZAHLER S., POHL U., GERHARDT H., SCHNITTLER H.J., MONTANEZE. (2015). Endothelial Alpha-Parvin Controls Integrity of Developing Vasculature and Is Required for Maintenance of Cell-Cell Junctions. Circulation Research 117: 29-40. https://doi.org/10.1161/CIRCRESAHA.117.305818

FRANCIS S. E., GOH K. L., HODIVALA-DILKE K., BADER B. L., STARK M., DAVIDSON D., HYNES R. O. (2002). Central Roles of a $5 \beta 1$ Integrin and Fibronectin in Vascular Development in Mouse Embryos and Embryoid Bodies. Arteriosclerosis, Thrombosis, and Vascular Biology 22: 927-933. https://doi.org/10.1161/01. ATV.0000016045.93313.F2

FRANCO C. A., JONES M. L., BERNABEU M. O., GEUDENS I., MATHIVET T., ROSA A., LOPES F. M., LIMA A. P., RAGAB A., COLLINS R. T., PHNG L.K., COVENEY P. V., GERHARDT H. (2015). Dynamic Endothelial Cell Rearrangements Drive Developmental Vessel Regression. PLOS Biology 13: e1002125. https://doi. org/10.1371/journal.pbio.1002125

FRIEDRICH E. B., LIU E., SINHA S., COOK S., MILSTONE D. S., MACRAE C. A., MARIOTTI M., KUHLENCORDT P. J., FORCE T., ROSENZWEIG A., ST-ARNAUD R., DEDHAR S., GERSZTEN R. E. (2004). Integrin-Linked Kinase Regulates Endothelial Cell Survival and Vascular Development. Molecular and Cellular Biology 24: 8134-8144. https://doi.org/10.1128/MCB.24.18.8134-8144.2004
FUKUSHIMA Y., NISHIYAMA K., KATAOKA H., FRUTTIGER M., FUKUHARA S. NISHIDA K., MOCHIZUKI N., KURIHARA H., NISHIKAWA S.I., UEMURA A (2020). RhoJ integrates attractive and repulsive cues in directional migration of endothelial cells. The EMBO Journal 39: 101-118. https://doi.org/10.15252/ embj.2019102930

GARDEL M. L., SCHNEIDER I. C., ARATYN-SCHAUS, Y., WATERMAN C. M. (2010). Mechanical Integration of Actin and Adhesion Dynamics in Cell Migration. Annual Review of Cell and Developmental Biology 26:315-333. https://doi.org/10.1146/ annurev.cellbio.011209.122036

GARMY-SUSINI B., JIN H., ZHU Y., SUNG R.J., HWANG R., VARNER J. (2005) Integrin a4 $31-\mathrm{VCAM}-1$-mediated adhesion between endothelial and mura cells is required for blood vessel maturation. Journal of Clinical Investigation 115: 1542-1551. https://doi.org/10.1172/JCI23445

GEIGER B., YAMADA K. M. (2011). Molecular Architecture and Function of Matrix Adhesions. Cold Spring Harbor Perspectives in Biology 3: a005033-a005033. https://doi.org/10.1101/cshperspect.a005033

GERMAIN M., DE ARCANGELIS A., ROBINSON S. D., BAKER M., TAVORA B., D'AMICO G., SILVA R., KOSTOUROU V., REYNOLDS L. E., WATSON A., JONES J. L., GEORGES-LABOUESSE E., HODIVALA-DILKE K. (2010). Genetic ablation of the alpha 6-integrin subunit in Tie1Cre mice enhances tumour angiogenesis. The Journal of Pathology 220: 370-381. https://doi.org/10.1002/path.2654

GERMAN A. E., MAMMOTO T., JIANG E., INGBER D. E., MAMMOTO A. (2014). Paxillin controls endothelial cell migration and tumor angiogenesis by altering neuropilin 2 expression. Journal of Cell Science 127: 1672-1683. https://doi. org $/ 10.1242 /$ jcs. 132316

GRAUPERA M., POTENTE M. (2013). Regulation of angiogenesis by PI3K signaling networks. Experimental Cell Research 319:1348-1355. https://doi.org/10.1016/j. yexcr.2013.02.021

HALE A. J., TER STEEGE E., DEN HERTOG J. (2017). Recent advances in understanding the role of protein-tyrosine phosphatases in development and disease. Developmental Biology 428: 283-292. https://doi.org/10.1016/j.ydbio.2017.03.023

HANAHAN D., FOLKMAN J. (1996). Patterns and Emerging Mechanisms of the Angiogenic Switch during Tumorigenesis. Cell 86: 353-364. https://doi. org/10.1016/S0092-8674(00)80108-7

HORTON E. R., BYRON A., ASKARI J. A., NG D. H. J., MILLON-FRÉMILLON A., ROBERTSON J., KOPER E. J., PAUL N. R., WARWOOD S., KNIGHT D., HUMPHRIES J. D., HUMPHRIES M. J. (2015). Definition of a consensus integrin adhesome and its dynamics during adhesion complex assembly and disassembly. Nature Cell Biology 17: 1577-1587. https://doi.org/10.1038/ncb3257

HUANG X. Z., WU J. F., FERRANDO R., LEE J. H., WANG Y. L., FARESE R. V., SHEPPARD D. (2000). Fatal Bilateral Chylothorax in Mice Lacking the Integrin a931. Molecular and Cellular Biology 20: 5208-5215. https://doi.org/10.1128/ MCB.20.14.5208-5215.2000

HYNES R. O. (2002). Integrins. Cell 110: 673-687. https://doi.org/10.1016/S0092 8674(02)00971-6

IRUELA-ARISPE M. L., BEITEL G. J. (2013). Tubulogenesis. Development 140 2851-2855. https://doi.org/10.1242/dev.070680

JIN Y., LIU Y., LIN Q., LI J., DRUSO J. E., ANTONYAK M. A., MEININGER C. J. ZHANG S. L., DOSTAL D. E., GUAN J.L., CERIONE R. A., PENG X. (2013). Deletion of Cdc42 Enhances ADAM17-Mediated Vascular Endothelial Growth Factor Receptor 2 Shedding and Impairs Vascular Endothelial Cell Survival and Vasculogenesis. Molecular and Cellular Biology 33: 4181-4197. https://doi. org/10.1128/MCB.00650-13

KARTHIK S., DJUKIC T., KIM J.D., ZUBER B., MAKANYA A., ODRIOZOLA A., HLUSHCHUK R., FILIPOVIC N., JIN S. W., DJONOV V. (2018). Synergistic interaction of sprouting and intussusceptive angiogenesis during zebrafish caudal vein plexus development. Scientific Reports 8: 9840. https://doi.org/10.1038/ s41598-018-27791-6

KIM S., BELL K., MOUSA S. A., VARNER J. A. (2000). Regulation of Angiogenesis in Vivo by Ligation of Integrin a $5 \beta 1$ with the Central Cell-Binding Domain of Fibronectin. The American Journal of Pathology 156: 1345-1362. https://doi org/10.1016/S0002-9440(10)65005-5

KONDRYCHYN I., KELLY D. J., CARRETERO N. T., NOMORI A., KATO K., CHONG J., NAKAJIMA H., OKUDA S., MOCHIZUKI N., PHNG L.K. (2020). MarcksI1 modulates endothelial cell mechanoresponse to haemodynamic forces to control blood vessel shape and size. Nature Communications 11: 5476. https:// doi.org/10.1038/s41467-020-19308-5 
KOSTOUROU V., LECHERTIER T., REYNOLDS L. E., LEES D. M., BAKER M., JONES D. T., TAVORA B., RAMJAUN A. R., BIRDSEY G. M., ROBINSON S. D., PARSONS M., RANDI A. M., HART I. R., HODIVALA-DILKE K. (2013). FAK-heterozygous mice display enhanced tumour angiogenesis. Nature Communications 4: 2020. https://doi.org/10.1038/ncomms3020

KOSTOUROU V., PAPALAZAROU V. (2014). Non-collagenous ECM proteins in blood vessel morphogenesis and cancer. Biochimica et Biophysica Acta (BBA)- General Subjects 1840: 2403-2413. https://doi.org/10.1016/j.bbagen.2014.02.018

LAVIÑA B., CASTRO M., NIAUDET C., CRUYS B., ÁLVAREZ-AZNAR A., CARMELIET P., BENTLEY K., BRAKEBUSCH C., BETSHOLTZ C., GAENGEL K. (2018). Defective endothelial cell migration in the absence of Cdc42 leads to capillary-venous malformations. Development 145: dev161182. https://doi.org/10.1242/dev.161182

LEE J., BORBOA A. K., CHUN H. B., BAIRD A., ELICEIRI B. P. (2010). Conditional Deletion of the Focal Adhesion Kinase FAK Alters Remodeling of the Blood-Brain Barrier in Glioma. Cancer Research 70: 10131-10140. https://doi. org/10.1158/0008-5472.CAN-10-2740

LEE T.H., SENG S., LI H., KENNEL S. J., AVRAHAM H. K., AVRAHAM S. (2006). Integrin Regulation by Vascular Endothelial Growth Factor in Human Brain Microvascular Endothelial Cells. Journal of Biological Chemistry 281: 40450-40460. https://doi.org/10.1074/jbc.M607525200

LEI L., LIU D., HUANG Y., JOVIN I., SHAI S.Y., KYRIAKIDES T., ROSS R. S., GIORDANO F. J. (2008). Endothelial Expression of $\beta 1$ Integrin Is Required for Embryonic Vascular Patterning and Postnatal Vascular Remodeling. Molecular and Cellular Biology 28: 794-802. https://doi.org/10.1128/MCB.00443-07

LIM S.T., CHEN X. L., TOMAR A., MILLER N. L.G., YOO J., SCHLAEPFER D. D. (2010). Knock-in Mutation Reveals an Essential Role for Focal Adhesion Kinase Activity in Blood Vessel Morphogenesis and Cell Motility-Polarity but Not Cell Proliferation. Journal of Biological Chemistry 285: 21526-21536. https://doi. org/10.1074/jbc.M110.129999

LUGANO R., RAMACHANDRAN M., DIMBERG A. (2019). Tumor angiogenesis: causes, consequences, challenges and opportunities. Cellular and Molecular Life Sciences 77: 1745-1770. https://doi.org/10.1007/s00018-019-03351-7

MAHABELESHWAR G. H., FENG W., PHILLIPS D. R., BYZOVA T. V. (2006). Integrin signaling is critical for pathological angiogenesis. Journal of Experimental Medicine 203: 2495-2507. https://doi.org/10.1084/jem.20060807

MAKANYA A. N., HLUSHCHUK R., DJONOV V. G. (2009). Intussusceptive angiogenesis and its role in vascular morphogenesis, patterning, and remodeling. Angiogenesis 12: 113-123. https://doi.org/10.1007/s10456-009-9129-5

MALAN D., ELISCHER A., HESSE M., WICKSTRÖM S. A., FLEISCHMANN B. K., BLOCH W. (2013). Deletion of integrin linked kinase in endothelial cells results in defective RTK signaling caused by caveolin 1 mislocalization. Development 140: 987-995. https://doi.org/10.1242/dev.091298

MOHAMMADI H., SAHAI E. (2018). Mechanisms and impact of altered tumour mechanics. Nature Cell Biology 20: 766-774. https://doi.org/10.1038/s41556018-0131-2

MONKLEY S. J., KOSTOUROU V., SPENCE L., PETRICH B., COLEMAN S., GINSBERG M. H., PRITCHARD C. A., CRITCHLEY D. R. (2011). Endothelial cell talin1 is essential for embryonic angiogenesis. Developmental Biology 349: 494-502. https://doi.org/10.1016/j.ydbio.2010.11.010

MONTANEZ E., WICKSTRÖM S. A., ALTSTÄTTER J., CHU H., FÄSSLER R. (2009). a-parvin controls vascular mural cell recruitment to vessel wall by regulating RhoA/ROCK signalling. The EMBO Journal28:3132-3144. https://doi.org/10.1038/ emboj.2009.295

NIKOLOPOULOS S. N., BLAIKIE P., YOSHIOKA T., GUO W., GIANCOTTI F. G. (2004). Integrin $\beta 4$ signaling promotes tumor angiogenesis. Cancer Cell 6: 471-483. https://doi.org/10.1016/j.ccr.2004.09.029

NIKOLOPOULOU P. A., KOUFAKI M. A., KOSTOUROU V. (2021). The Adhesome Network: Key Components Shaping the Tumour Stroma. Cancers 13: 525. https:// doi.org/10.3390/cancers13030525

NILAND S., EBLE J. A. (2012). Integrin-Mediated Cell-Matrix Interaction in Physiological and Pathological Blood Vessel Formation. Journal of Oncology 2012: 1-25. https://doi.org/10.1155/2012/125278

NISHIYA N., KIOSSES W. B., HAN J., GINSBERG M. H. (2005). An a4 integrin-paxillin-Arf-GAP complex restricts Rac activation to the leading edge of migrating cells. Nature Cell Biology 7: 343-352. https://doi.org/10.1038/ncb1234
NOHATA N., UCHIDA Y., STRATMAN A. N., ADAMS R. H., ZHENG Y., WEINSTEIN B M., MUKOUYAMA Y.S., GUTKIND J. S. (2016). Temporal-specific roles of Rac1 during vascular development and retinal angiogenesis. Developmental Biology 411: 183-194. https://doi.org/10.1016/j.ydbio.2016.02.005

NOWAK-SLIWINSKA P., ALITALO K., ALLEN E., ANISIMOV A., APLIN A. C., AUERBACH R., AUGUSTIN H. G., BATES D. O., VAN BEIJNUM J. R., BENDER R. H. F., BERGERS G., BIKFALVI A., BISCHOFF J., BÖCK B. C., BROOKS P. C., BUSSOLINO F., CAKIR B., CARMELIET P., CASTRANOVA D., CIMPEAN A. M., CLEAVER O, COUKOS G., DAVIS G. E., DE PALMA M., DIMBERG A., DINGS R. P. M., DJONOV V., DUDLEY A. C., DUFTON N. P., FENDT S.M. et al. (2018). Consensus guidelines for the use and interpretation of angiogenesis assays. Angiogenesis 21: 425-532. https://doi.org/10.1007/s10456-018-9613-x

PARK H., YAMAMOTO H., MOHN L., AMBÜHL L., KANAI K., SCHMIDT I., KIM K.P., FRACCAROLI A., FEIL S., JUNGE H. J., MONTANEZ E., BERGER W., ADAMS R. H. (2019). Integrin-linked kinase controls retinal angiogenesis and is linked to Wnt signaling and exudative vitreoretinopathy. Nature Communications 10: 5243. https://doi.org/10.1038/s41467-019-13220-3

PEARSON J. D. (2010). Endothelial progenitor cells-an evolving story. Microvascular Research 79: 162-168. https://doi.org/10.1016/j.mvr.2009.12.004

PEDROSA A.R., BODRUG N., GOMEZ-ESCUDERO J., CARTER E. P., REYNOLDS L. E., GEORGIOU P. N., FERNANDEZ I., LEES D. M., KOSTOUROU V., ALEXOPOULOU A. N., BATISTA S., TAVORA B., SERRELS B., PARSONS M., ISKRATSCH T., HODIVALA-DILKE K. M. (2019). Tumor Angiogenesis Is Differentially Regulated by Phosphorylation of Endothelial Cell Focal Adhesion Kinase Tyrosines-397 and -861. Cancer Research 79:4371-4386. https://doi.org/10.1158/0008-5472.CAN-18-3934

PHNG L.K., GEBALA V., BENTLEY K., PHILIPPIDES A., WACKER A., MATHIVET T., SAUTEUR L., STANCHI F., BELTING H.G., AFFOLTER M., GERHARDT H. (2015). Formin-Mediated Actin Polymerization at Endothelial Junctions Is Required for Vessel Lumen Formation and Stabilization. Developmental Cell 32: 123-132. https://doi.org/10.1016/j.devcel.2014.11.017

PITTER B., WERNER A.C., MONTANEZE. (2018). Parvins Are Required for Endothelial Cell-Cell Junctions and Cell Polarity During Embryonic Blood Vessel Formation. Arteriosclerosis, Thrombosis, and Vascular Biology 38: 1147-1158. https://doi. org/10.1161/ATVBAHA.118.310840

PLUSKOTA E., DOWLING J. J., GORDON N., GOLDEN J. A., SZPAK D., WEST X.X. Z., NESTOR C., MA Y.Q., BIALKOWSKA K., BYZOVA T., PLOW E. F. (2011). The integrin coactivator Kindlin-2 plays a critical role in angiogenesis in mice and zebrafish. Blood 117: 4978-4987. https://doi.org/10.1182/blood-2010-11-321182

POTENTE M., GERHARDT H., CARMELIET P. (2011). Basic and Therapeutic Aspects of Angiogenesis. Cell 146: 873-887. https://doi.org/10.1016/j.cell.2011.08.039

POZZI A., MOBERG P. E., MILES L. A., WAGNER S., SOLOWAY P., GARDNER H. A (2000). Elevated matrix metalloprotease and angiostatin levels in integrin alpha 1 knockout mice cause reduced tumor vascularization. Proceedings of the National Academy of Sciences 97: 2202-2207. https://doi.org/10.1073/pnas.040378497

PULOUS F. E., CARNEVALE J. C., AL-YAFEAI Z., PEARSON B. H., HAMILTON J. A. G., HENRY C. J., ORR A. W., PETRICH B. G. (2020). Talin-dependent integrin activation is required for endothelial proliferation and postnatal angiogenesis. Angiogenesis 24: 177-190. https://doi.org/10.1007/s10456-020-09756-4

RAMJAUN A. R., HODIVALA-DILKE K. (2009). The role of cell adhesion pathways in angiogenesis. The International Journal of Biochemistry \& Cell Biology 41:521-530. https://doi.org/10.1016/j.biocel.2008.05.030

REYNOLDS A. R., HART I. R., WATSON A. R., WELTI J. C., SILVA R. G., ROBINSON S. D., DA VIOLANTE G., GOURLAOUEN M., SALIH M., JONES M. C., JONES D. T., SAUNDERS G., KOSTOUROU V., PERRON-SIERRA F., NORMAN J. C., TUCKER G. C., HODIVALA-DILKE K. M. (2009). Stimulation of tumor growth and angiogenesis by low concentrations of RGD-mimetic integrin inhibitors. Nature Medicine 15: 392-400. https://doi.org/10.1038/nm.1941

REYNOLDS L. E., WYDER L., LIVELY J. C., TAVERNA D., ROBINSON S. D., HUANG X., SHEPPARD D., HYNES R. O., HODIVALA-DILKE K. M. (2002). Enhanced pathological angiogenesis in mice lacking $\beta 3$ integrin or $\beta 3$ and $\beta 5$ integrins. Nature Medicine 8: 27-34. https://doi.org/10.1038/nm0102-27

RISAU W. (1997). Mechanisms of angiogenesis. Nature 386: 671-674. https://doi. org/10.1038/386671a0

SHEN T.L., PARK A. Y.J., ALCARAZ A., PENG X., JANG I., KONI P., FLAVELL R. A., GU H., GUAN J.L. (2005). Conditional knockout of focal adhesion kinase in endothelial cells reveals its role in angiogenesis and vascular development in late embryogenesis. Journal of Cell Biology 169: 941-952. https://doi.org/10.1083/ jcb.200411155 
SUNDARARAMAN A., FUKUSHIMA Y., NORMAN J. C., UEMURA A., MELLOR H. (2020). RhoJ Regulates a5 $\beta 1$ Integrin Trafficking to Control Fibronectin Remodeling during Angiogenesis. Current Biology 30:2146-2155.e5. https://doi.org/10.1016/j. cub.2020.03.042

TAN C., CRUET-HENNEQUART S., TROUSSARD A., FAZLI L., COSTELLO P., SUTTON K., WHEELER J., GLEAVE M., SANGHERA J., DEDHAR S. (2004). Regulation of tumor angiogenesis by integrin-linked kinase (ILK). Cancer Cell 5: 79-90. https:// doi.org/10.1016/S1535-6108(03)00281-2

TAN W., PALMBY T. R., GAVARD J., AMORNPHIMOLTHAM P., ZHENG Y., GUI J. S. (2008). An essential role for Rac1 in endothelial cell function and vascular development. The FASEB Journal 22: 1829-1838. https://doi.org/10.1096/fj.07-096438

TANJORE H., ZEISBERG E. M., GERAMI-NAINI B., KALLURI R. (2008). $\beta 1$ integrin expression on endothelial cells is required for angiogenesis but not for vasculogenesis. Developmental Dynamics 237: 75-82. https://doi.org/10.1002/dvdy.21385

TAVORA B., BATISTA S., ALEXOPOULOU A.N., KOSTOUROU V., FERNANDEZ I., ROBINSON S.D., LEES D.M., SERRELS B., HODIVALA-DILKE K. (2014). Generation of point-mutant FAK knockin mice. genesis 52: 907-915. https://doi. org/10.1002/dvg.22823

TAVORA B., BATISTA S., REYNOLDS L. E., JADEJA S., ROBINSON S., KOSTOUROU V., HART I., FRUTTIGER M., PARSONS M., HODIVALA-DILKE K. M. (2010). Endothelial FAK is required for tumour angiogenesis. EMBO Molecular Medicine 2: 516-528. https://doi.org/10.1002/emmm.201000106

VOURET-CRAVIARI V., BOULTER E., GRALL D., MATTHEWS C., VAN OBBERGHENSCHILLING E. (2004). ILK is required for the assembly of matrix-forming adhesions and capillary morphogenesis in endothelial cells. Journal of Cell Science 117: 4559-4569. https://doi.org/10.1242/jcs.01331

WEINBERG S. H., MAIR D. B., LEMMON C. A. (2017). Mechanotransduction Dynamics at the Cell-Matrix Interface. Biophysical Journal 112: 1962-1974. https://doi. org/10.1016/j.bpj.2017.02.027

XU K., SACHARIDOU A., FU S., CHONG D. C., SKAUG B., CHEN Z. J., DAVIS G. E., CLEAVER O. (2011). Blood Vessel Tubulogenesis Requires Rasip1 Regulation of GTPase Signaling. Developmental Cell 20: 526-539. https://doi.org/10.1016/j. devcel.2011.02.010

YANG J.T., RAYBURN H., HYNES R.O. (1993). Embryonic mesodermal defects in alpha 5 integrin-deficient mice. Development 119: 1093-1105. https://doi. org/10.1242/dev.119.4.1093
YAU C. Y.F., WHEELER J. J., SUTTON K. L., HEDLEY D. W. (2005). Inhibition of Integrin-Linked Kinase by a Selective Small Molecule Inhibitor, QLT0254, Inhibits the PI3K/PKB/mTOR, Stat3, and FKHRPathways and Tumor Growth, and Enhances Gemcitabine-Induced Apoptosis in Human Orthotopic Primary Pancreatic Cancer Xenografts. CancerResearch 65: 1497-1504. https://doi.org/10.1158/0008-5472. CAN-04-2940

YUAN L., SACHARIDOU A., STRATMAN A. N., LE BRAS A., ZWIERS P. J., SPOKES K., BHASIN M., SHIH S., NAGY J. A., MOLEMA G., AIRD W. C., DAVIS G. E., OETTGEN P. (2011). RhoJ is an endothelial cell-restricted Rho GTPase that mediates vascular morphogenesis and is regulated by the transcription factor ERG. Blood 118: 1145-1153. https://doi.org/10.1182/blood-2010-10-315275

ZAHRA F. T., SAJIB M. S., ICHIYAMA Y., AKWII R. G., TULLAR P. E., COBOS C. MINCHEW S. A., DOÇI C. L., ZHENG Y., KUBOTA Y., GUTKIND J. S., MIKELIS C. M. (2019). Endothelial RhoA GTPase is essential for in vitro endothelial functions but dispensable for physiological in vivo angiogenesis. Scientific Reports 9:11666. https://doi.org/10.1038/s41598-019-48053-z

ZAIDEL-BAR R., GEIGER B. (2010). The switchable integrin adhesome. Journal of Cell Science 123: 1385-1388. https://doi.org/10.1242/jcs.066183

ZANOTELLI M. R., REINHART-KING C. A. (2018). Mechanical Forces in Tumor Angiogenesis. In Biomechanics in Oncology (Ed. Dong C., Zahir N., K. Konstantinos). Advances in Experimental Medicine and Biology, Vol. 1092. Springer International Publishing, pp. 91-112. https://doi.org/10.1007/978-3-319-95294-9_6

ZHANG Z., RAMIREZ N. E., YANKEELOV T. E., LI Z., FORD L. E., QI Y., POZZI A., ZUTTER M. M. (2008). a2 $\beta 1$ integrin expression in the tumor microenvironment enhances tumor angiogenesis in a tumor cell-specific manner. Blood 111: 19801988. https://doi.org/10.1182/blood-2007-06-094680

ZHAOX., PENG X., SUN S., PARKA. Y.J., GUAN J.L. (2010). Role of kinase-independent and -dependent functions of FAK in endothelial cell survival and barrier function during embryonic development. Journal of Cell Biology 189: 955-965. https://doi. org/10.1083/jcb.200912094

ZOVEIN A. C., LUQUE A., TURLO K. A., HOFMANN J. J., YEE K. M., BECKER M. S. FASSLER R., MELLMAN I., LANE T. F., IRUELA-ARISPE M. L. (2010). $\beta 1$ Integrin Establishes Endothelial Cell Polarity and Arteriolar Lumen Formation via a Par3Dependent Mechanism. Developmental Cell 18: 39-51. https://doi.org/10.1016/j. devcel.2009.12.006 